\title{
Correction to: Synoptic conditions and potential causes of the extreme heavy rainfall event of January 2009 over Mindanao Island, Philippines
}

\author{
Lyndon Mark Payanay Olaguera ${ }^{1,2}$ (D) . Michelle Español Caballar ${ }^{1}$. \\ Joseph Cabacungan De Mata ${ }^{1}$. Loida Ann Torres Dagami ${ }^{1}$ Jun Matsumoto ${ }^{3,4}$. \\ Hisayuki Kubota ${ }^{4,5}$
}

Published online: 12 November 2021

(c) The Author(s) 2021

\section{Correction to: Natural Hazards https://doi.org/10.1007/s11069-021-04934-z}

The article "Synoptic conditions and potential causes of the extreme heavy rainfall event of January 2009 over Mindanao Island, Philippines", written by Lyndon Mark Payanay Olaguera · Michelle Español Caballar · Joseph Cabacungan De Mata · Loida Ann Torres Dagami · Jun Matsumoto $\cdot$ Hisayuki Kubota, was originally published electronically on the

The original article can be found online at https://doi.org/10.1007/s11069-021-04934-z.

Lyndon Mark Payanay Olaguera

lmolaguera@observatory.ph

Michelle Español Caballar

michelle.caballar@obf.ateneo.edu

Joseph Cabacungan De Mata

joseph.c.demata@obf.ateneo.edu

Loida Ann Torres Dagami

loida.dagami@obf.ateneo.edu

Jun Matsumoto

jun@tmu.ac.jp

Hisayuki Kubota

hkubota@ep.sci.hokudai.ac.jp

1 Physics Department, Ateneo de Manila University, 1108 Loyola Heights Quezon City, Philippines

2 Regional Climate Systems Laboratory, Manila Observatory, Quezon City, Ateneo de Manila University Campus, 1108 Loyola Heights, Quezon City, Philippines

3 Department of Geography, Tokyo Metropolitan University, 1-1 Minami-Osawa, Hachioji-Shi, Tokyo 192-0397, Japan

4 Dynamic Coupling of Ocean-Atmosphere-Land Research Program, Japan Agency for Marine Earth Science and Technology, Yokosuka, Kanagawa 237-0061, Japan

5 Faculty of Science, Department of Earth and Planetary Sciences, Hokkaido University, Kita-10 Nishi-8, Kita-ku, Sapporo, Hokkaido 060-0810, Japan 
publisher's internet portal on July 15, 2021 without open access. With the author(s)' decision to opt for Open Choice, the copyright of the article changed on September 12, 2021 to ()The Author(s) 2021 and the article is forthwith distributed under a Creative Commons Attribution 4.0 International License, which permits use, sharing, adaptation, distribution and reproduction in any medium or format, as long as you give appropriate credit to the original author(s) and the source, provide a link to the Creative Commons licence, and indicate if changes were made. The images or other third party material in this article are included in the article's Creative Commons licence, unless indicated otherwise in a credit line to the material. If material is not included in the article's Creative Commons licence and your intended use is not permitted by statutory regulation or exceeds the permitted use, you will need to obtain permission directly from the copyright holder. To view a copy of this licence, visit http://creativecommons.org/licenses/by/4.0.

The original article has been corrected.

Publisher's Note Springer Nature remains neutral with regard to jurisdictional claims in published maps and institutional affiliations. 